\title{
THE ROLE OF SELECTED HIGHER EDUCATIONAL INSTITUTIONS (HEIS) AND LOCAL GOVERNMENT UNITS ON INTEGRATING FOOD HERITAGE RESEARCH INTO POLITICAL PRIORITIES: A PUBLIC POLICY ANALYSIS OF LUZON ISLAND, PHILIPPINES
}

\author{
Avi Ben P. Andalecio* \\ Research Associate, Research Center for Social Sciences and Education (RCSSEd) \\ College of Tourism and Hospitality Management, University of Santo Tomas, Philippines \\ *Corresponding author's email: apandalecio@ust.edu.ph
}

\begin{abstract}
The purpose of this study is to show how food heritage, specifically Filipino Pancit, define the culture of their citizens, investigate the efforts of Local Government Units (LGUs), and examine the role of a selected Higher Educational Institution (HEI) as a partner of LGUs in safeguarding food heritage. The researcher used frameworks from international and national cultural agencies and researchers. Observation and indepth interviews were also used for the documentation process through case study technique, which examined the aspects of statutory control and safeguarding mechanisms to determine the political priorities of involved LGUs and the selected HEl's role in safeguarding food heritage in the islands of Luzon, Philippines. Findings suggest that LGUs' sheer political will, knowledge, and awareness on issues on heritage conservation, openness, sustainable practices, and multi-stakeholder participation are essential in robust protection vis-à-vis culture and heritage conservation. This comes with the active participation of stakeholders, especially academic institutions, which provide expertise and extra leg work on research backed by their advocacy rooted on Filipino identity and sustainability to support policies of the government. Ultimately, research-based policymaking is key to open opportunities not just on intangible cultural heritage like Filipino Pancit but on culture and heritage conservation in general.
\end{abstract}

Keywords: Intangible Cultural Heritage; Public Policy; Local Government Unit; Higher Educational Institution 


\section{INTRODUCTION}

In the field of cultural heritage conservation and conservation science, policymakers are perceived to have a significant role when it comes to decision-making as they constitutionally and personally benefit through historical past and its preservation. Regardless, recognition is minimal in communication and collaboration with this group of stakeholders, lacking awareness, and contribution to heritage policy development.

Being a large proportion of cultural heritage and its conservation lie in the public domain, does most of the research funding for science, conservation science is deeply influenced by the government's policy making with reference to heritage and science (Lee, 2016). Successively, this sector must be cognizant in conjunction with the significance of good communication as it builds firm relationships and vigorous contribution at policy making level.

\section{Food Heritage in the Philippines}

Historical and cultural development of the society greatly influenced the cuisine in the Philippines. The cooking method of a certain dish is then passed down through generations and compared to other places as it features distinctness. Therefore, acknowledging food as a heritage and legacy of the community. The United Nations Educational, Scientific and Cultural Organization (UNESCO) describes heritage as "legacies from the past, what we live with today, and what we individually or collectively pass on to future generations" (UNESCO, 1972). Subsequently, culinary traditions originate from the impacts and changes of history of a specific location; at this point, society keeps on utilizing it from an individual, to the family then to the community; and further protects, maintains, and shares it to future generations. Hence, in the viewpoint of UNESCO, culinary tradition is viewed as a component of the primary areas of the elusive cultural heritage under social practices, ceremonies, and celebratory occasions (UNESCO, 2003). 
As an identity of the people, food exhibits great importance that adds to its uniqueness. Its significance depends on historical, aesthetic, social and symbolic aspects. It is vital to break down these specifics as they add to the community's story and relevance and how food gradually evolves as part of the people's heritage.

This paper draws upon a project funded by the National Commission for Culture and the Arts (NCCA) which focuses to answer the central question: what are the actions taken by the primary stakeholders on food heritage preservation in Luzon Island, Philippines and what plan of action should be considered by the LGUs to conserve their respective intangible culinary heritage? Thus, this paper answered specific questions (1) what are the policies of selected LGUs on food heritage preservation, specifically its public policies? (2) what are the roles of selected HEls as a contributor to LGUs on the preservation of food heritage? And (3) what are the recommended actions to support food heritage policy development for LGUs?

In any case, before proceeding towards these essential queries, a primary question to ask is why is it imperative to persuade policymakers regarding the value of conservation science? Perhaps the key reason, even before that of resource allocation, is that policymakers have the capability to put heritage and its conservation as a priority within the bounds of political plans, relating to contemporary issues and difficulties.

For instance, through the acknowledgment that heritage is a key component of practicing human rights, it becomes significant for policymakers to place value on heritage conservation and conservation science as a significant action through which heritage can be guaranteed for future generations.

\section{Research in The Context of Heritage}

HEls offer numerous degree programs by a selection of colleges and universities. These can either be public or private. Last August 2010, Commission on Higher Education showed records of 1,573 private and 607 public HEls in the country (CHED, 2011). HEls basically offer 
research extension services intended for the government as represented by the National Commission for Culture and the Arts (NCCA), Department of Tourism (DOT), and other related agencies.

Research has been a priority of DOT by providing grants to various academicians. The results from these researches then become a basis for policy development through acknowledging and responding to issues and concerns of various trends in the travel industry. Moreover, various studies on traditional food and food product toward identity have been made in numerous ASEAN nations like Malaysia. However, limited studies are done when it comes to heritage context (Ramli et al., 2015). Consequently, HEls assume a remarkable role on Policy Development through research along with the government, since it has now become cognizant with regards to the need of an evidence-based approach of policy making.

Public policy through an evidence-based approach is based on research that has passed some form of quality assurance and tests. This separates it from public policy based on normal or more conventional policy development processes where intuitive appeal, tradition, politics, or the extension of existing practice may set the policy agenda. Pawson (2002) describes evidencebased policy in a casual description: "Research should attempt to pass on collective wisdom about the successes and failure of previous initiatives in particular policy domains. The prize is also a big one that such an endeavor could provide the antidote to policy making's frequent lapses into crowd pleasing, political pandering, window dressing and god-acting."

Comprehension of evidence-based policy tend to differ. However, in the study conducted by Reid (2003) as cited in O'Dwyer (2004), a great number of policy makers used the term to suggest that policy was substantially informed by data and proof. The most common definition was "making significant use of research evidence to inform the development and implementation of your policies." 


\section{Policymakers and Policies}

Policymakers are considered to have influences on the allocation of resources to heritage and its conservation, since it also goes along with the establishment of cultural heritage conservation as a political priority. If the decision made by the policymakers becomes successful, it will eventually preserve long-term sustainable heritage policies.

In most cases, evidence is continuously used by policy makers in decision-making. Hence, making it significant for conservation science research to present evidence concerning the advantages it brings to heritage conservation. Provided that it can give valuable evidence, this will cause impelling cultural heritage conservation towards political agenda.

Policymakers include conventional groups, opinion-makers, and institutes that are involved in the formation of political ideas and the policymaking influence. These are not limited to local people, but also professionals who are employed under international organizations, foreign institutes, and non-governmental organizations (NGOs). Furthermore, whole process of policymaking and the people involved differ from one culture to another.

The methods in policy making for cultural heritage tend to change, provided that the types of policymakers in heritage, presentation methods, and policy execution varies from one place to another. Hence, the people involved towards policymaking for cultural heritage are equally diverse, contingent on the process of initiating, discussing, drafting, adopting, and deciding. Though, it is challenging to systematically list all types of policymakers, common types can be categorized as shown in Figure 1. 


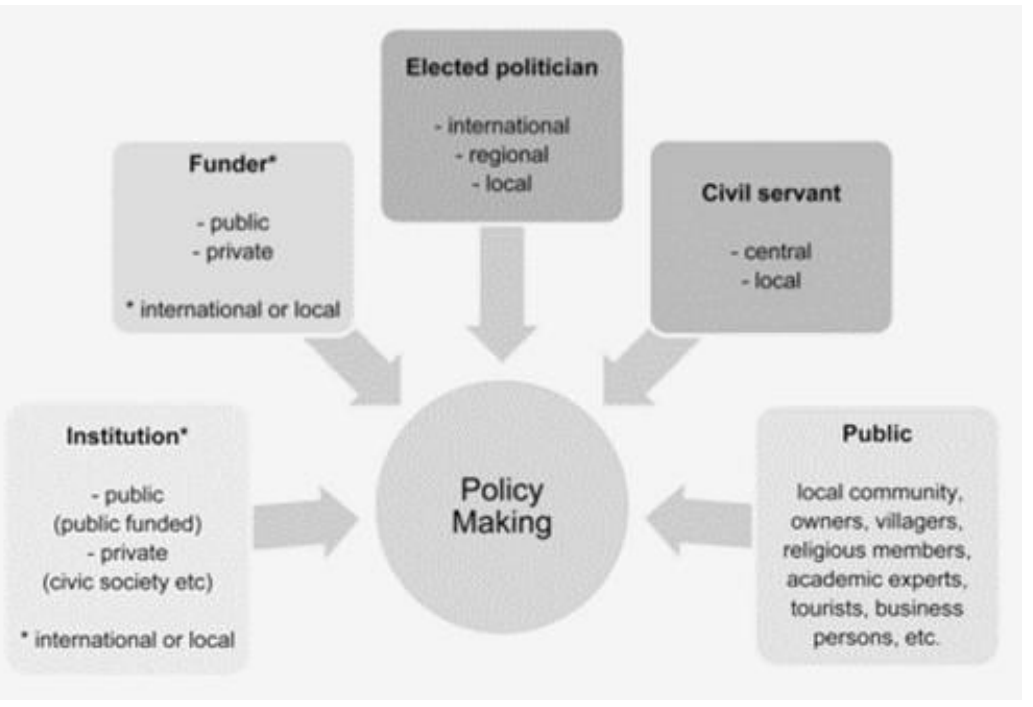

Figure 1: Types of Policymakers (Lee, 2015)

The role of policymakers is of great importance in policy development and implementation as these individuals are expected to formulate, debate, and enact policies. They may also be under governmental body, political parties, public or private institutes, interest groups, and people who establish a direction and urgency for an action to benefit a society, a nation, or community (Lee, 2015). Civil servants are frequently engaged directly to the heritage sector and later become witnesses to its actual difficulties.

\section{METHOD}

This research used the qualitative approach which focused on analyzing the stakeholders' perspectives. The researchers highlighted the identification of different heritage research evidence, specifically on the physical, oral, documentary, or archival. Below are the research tools that were used for each heritage evidence. 
Table 1. Tabular Summary of the Research Evidence and Tools as Aligned to the Theoretical Frameworks

\begin{tabular}{|c|c|c|c|}
\hline Research Evidence & Research Tools & Research Materials & Alignment to the Theoretical Frameworks \\
\hline Physical & $\begin{array}{l}\text { Observation and } \\
\text { Documentation }\end{array}$ & $\begin{array}{l}\text { Documentation Template for } \\
\text { Culinary Heritage (See Attachment) }\end{array}$ & $\begin{array}{l}2003 \text { UNESCO Convention for the Safeguarding of } \\
\text { Intangible Cultural Heritage (UNESCO, 2003) } \\
\text { Australia ICOMOS Burra Charter for Places of } \\
\text { Cultural Significance (Australia ICOMOS, 2013), } \\
\text { Republic Act No. 10066 (Congress of the Philippines, } \\
\text { 2009) and the Culinary Mapping (Sta. Maria, 2016) }\end{array}$ \\
\hline Oral & In-depth Interview & Questionnaire (See Attachment) & $\begin{array}{l}2003 \text { UNESCO Convention for the Safeguarding of } \\
\text { Intangible Cultural Heritage (UNESCO, 2003) }\end{array}$ \\
\hline $\begin{array}{l}\text { Documentary I } \\
\text { Archival }\end{array}$ & $\begin{array}{l}\text { Readings from Primary } \\
\text { and Secondary } \\
\text { References }\end{array}$ & $0=$ & $\begin{array}{l}\text { Australia ICOMOS Burra Charter for Places of } \\
\text { Cultural Significance (Australia ICOMOS, 2013) and } \\
\text { the Culinary Mapping (Sta. Maria, 2016) }\end{array}$ \\
\hline
\end{tabular}

\section{Subject and Subject Site}

The researchers focused on the geographical scope of the Luzon Island, specifically places that have existing, emerging, and potentially known pancit and the look for policies of LGUs on intangible cultural heritage. The basis for determining the sites was from the available references, local and national culinary historians, and promotional materials from different tourism-based offices that highlight Pancit as their primary or secondary tourism product and local culinary identity.

The researchers focused on the following regions: Region 1: llocos Region (llocos Norte and Ilocos Sur); Region 2: Cagayan Valley (Cagayan and Isabela); Region 3: Central Luzon (Pampanga, Bulacan, Bataan, Tarlac and Nueva Ecija); Region CAR: Cordillera Administrative Region (Abra); Region NCR: National Capital Region (Muntinlupa City, Pasay City, Makati City, Pasig City, City of Manila, San Juan City, Quezon City, Marikina City and Malabon City); Region 4A: CaLaBaRzon (Cavite, Laguna, Batangas, Rizal and Quezon); Region 4B: MiMaRoPa (Marinduque, Romblon and Palawan); and Region 5: Bicol Region (Camarines Sur and Albay). 


\section{Data Measures}

The following are the details of the different research tools used in the research: (1) Observation and Documentation - this research tool determined different details and concepts of Pancit by observing it as the local community's common lifestyle and documenting it based on the theoretical frameworks. The researchers used a template that was based from the concepts of heritage documentation from the policies of the National Commission for Culture and the Arts (NCCA), cultural mapping by the University of Santo Tomas Graduate School - Center for Conservation of Cultural Properties and the Environment in the Tropics (USTGS-CCCPET) (Zerrudo, 2008) and the culinary mapping template in a town or barangay (Sta. Maria, 2016); (2) In-depth Interview - this is a qualitative type of research that seeks to determine a comprehensive in-sight from a person with the condition of having only a small group of respondents (Boyce \& Neale, 2006). This established stakeholders' perspectives, specifically the LGUs, local culinary historians, restaurant owners, people who are known for practicing the culinary tradition, and nongovernment organizations (NGOs) who are managing and/or preserving the tradition on the culinary heritage significance as an intangible cultural property of the community and how it helps them in their lifestyle; and (3) Readings from Primary and Secondary References - as part of any heritage and cultural research, tedious archival and documentary work were required. This was the basis on the theoretical and conceptual frameworks for the implementation of the research. 


\section{Data Collection Procedure}

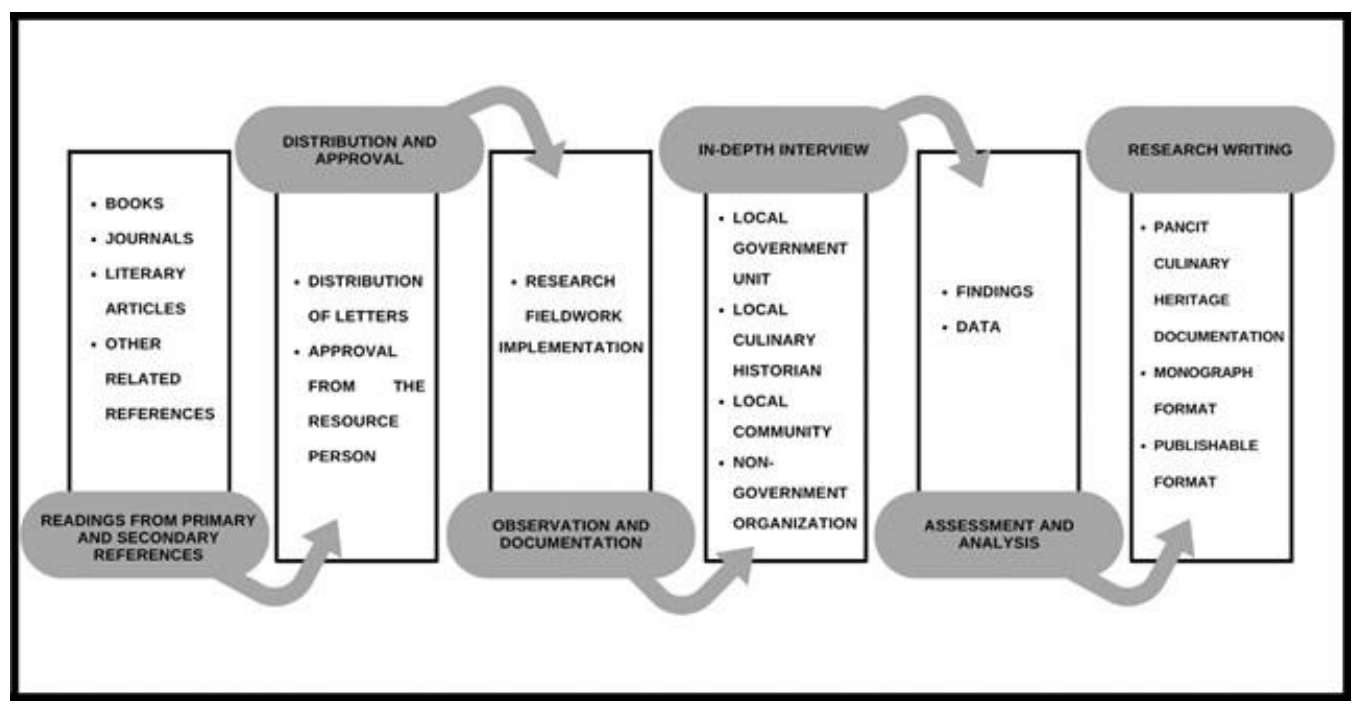

Figure 2. Representation of the Research Information Gathering Procedure

The information gathering procedure includes assessment and analysis of various references like books, journal articles or other related resources. For ethical standards, the researcher distributed appropriate letters of intent to various stakeholders and waited for their approval before the execution of the research fieldwork. Research fieldwork was implemented upon approval, specifically the observation and documentation of the culinary tradition, and indepth interviews to different stakeholders. Interpretation of findings and data gathered were then implemented after the fieldwork.

\section{Ethical Consideration}

For the ethical consideration of the research, the instruments used were reviewed and approved by the USTGS - Ethics Review Committee. The researchers constantly communicated with different LGUs, specifically their tourism or cultural and heritage office for proper coordination. During the documentation procedure, the participants had the privilege to choose among all the information needed by the researchers to practice intellectual property rights and data privacy. Afterwards, the participants were required to understand and to sign the consent 
form highlighting that all information gathered during the research were used for academic purposes only.

\section{Mode of Analysis}

The gathered information was analyzed by means of thematic analysis. The mode of analysis for the research was based on the following indicators/dimensions:

\section{Table 2. Indicators/Dimensions for the Research}

\section{Culinary Heritage Significance}

Historical Significance - this determines the story of Pancit based from the available physical, oral, archival and/or associated evidence. The story can be related from the preHispanic, Spanish, American, Japanese or the Third Republic, which will relate to the existence of the culinary tradition in a particular area.

Culinary Significance - this identifies the attachment of the food to the everyday lifestyle of the community and other people associated. Proper recipe standards, raw ingredients, process of cooking and food service are related

Agricultural Significance - this determines the relationship of the culinary tradition to the agricultural landscape, producing and process anchored in the raw ingredients and materials used to cook the dish.

Aesthetic Significance - this pertains to the physical consistency and appearance of the dish especially related to the way on how raw ingredients are combined and on how the dish is being plated in the desired serving utensils. The proper way of eating the food is also included, which is influenced by the local community.

Economic Significance - this determines the positive effects of the culinary tradition in the growth of a particular area for uplifting the lives of the community and contributing to the total production of goods and services offered

Health Significance - this determines the relationship of the culinary tradition to the required nutritional value especially for consumption.

Spiritual Significance - this highlights the significance of the culinary tradition to the religious and spiritual aspects of the local community.

Social Significance - this relates the culinary tradition to important events related to the area and to its local community. This is also discussing what the local community's perspective about the culinary tradition as it is part of their everyday lifestyle

Symbolic Significance - the culinary tradition is being interpreted as part of the local community's morals, values and ethical practices

\section{FINDINGS}

Interviews and observations were able to gather as much information as needed. Tables of the list of pancit dishes per region, provinces, cities, and municipalities is highlighted to further understand the status of each locale and how the LGUs approach the subject. Roles of selected HEls were also highlighted and a good reference point on the role of the academe and finally, the recommended plan of action to support food heritage policy development in the Philippines. 


\section{Examined Policies of Selected LGUs on Food Heritage Preservation by Looking into the Role of Public Policy on The Preservation of Food Heritage}

Table 3. Tabular Summary of the Regions in Luzon and the corresponding Pancit Dishes
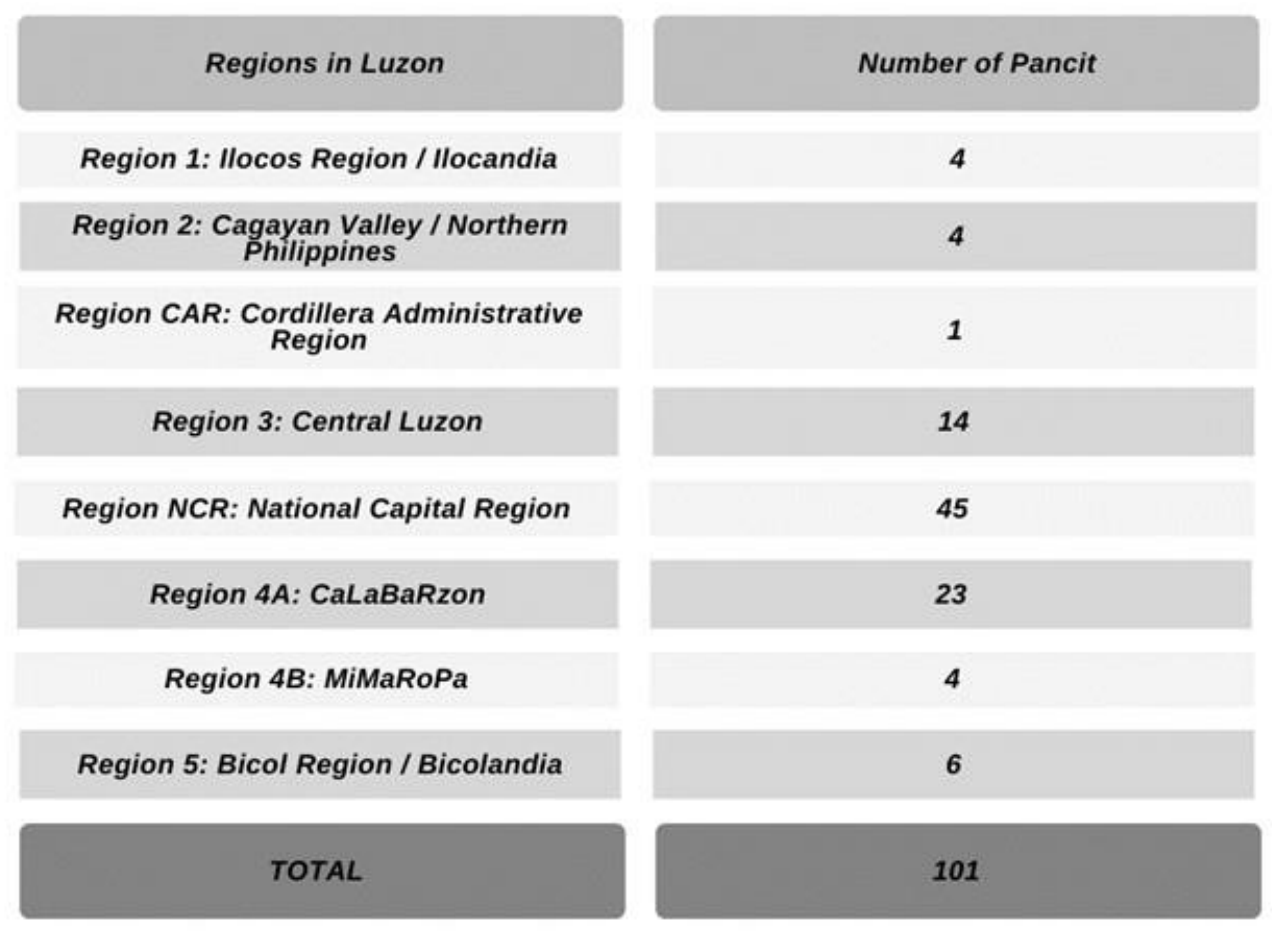

These regions are considerably abundant with a fusion of diverse background and ethnicity that shaped their cultural landscape and culinary prowess and identity. Among the twenty (20) provinces, twenty-seven (27) cities and twenty-six (26) municipalities, an impressive total of one hundred and one (101) pancit dishes were mapped and further explored for their well-known and significant variety from soup-based dishes, stir-fried local favorite, down to the least-known, exotic, and unique kind prepared and served for different occasions.

Each Pancit depicts uniqueness from one another which portray community significance. (See the Appendix for a Tabular Summary of the Regions, Provinces, Cities, Municipalities and their corresponding Pancit Dishes and current Policies) As an identity of the people, these Pancit Dishes exhibit great importance that adds to its exceptionality and distinction. This centrality 
depends on historical, aesthetic, social, and symbolical aspects. It is therefore imperative to break down these specifics as they add to the story and significance of the community and how food gradually evolves as a part of the heritage of the people. Hence, policies such as laws and ordinances are important to safeguard these community traditions which represent their identity. However, majority of the LGUs in Luzon have not taken initiative on the conservation of intangible cultural heritage. The City of Manila ordinances only focus on built structures and there is no existing ordinance that protects nor recognizes intangible cultural heritage. Other cities and municipalities have intangible cultural heritage recognition but only to the extent of lip-service and depends on prioritization of local elected officials. Almost all the cities and municipalities have non-existent policies or even recognition on intangible cultural heritage of their jurisdictions. The following themes better explain this phenomenon and will provide a contextual understanding on Philippine Public Administration in the context of food heritage safeguarding and protection.

\section{Prioritization and Political Will}

Politicians as the primary policymakers in the Philippines play an important role in heritage conservation. Sheer political will of the people in power can yield developments on advocacy movements mostly lobbied by non-state actors. Several examples taken from the results of this research will give contextual understanding on how significant prioritization is to all levels of the government from the national to local context. However, majority of the LGUs and their exercise of local autonomy as enshrined in the constitution greatly influences the quality of food heritage conservation efforts. Knowledge and awareness are keys to understand why these local executives continue to disregard the significance of the food heritage conservation in their jurisdiction as these variables influence their decision making. Majority of these people in power have no idea of what conservation is or its importance. Hence, prioritization is focused on other socioeconomic needs of their constituencies. It is obvious that majority of the politicians only pay attention on what seems to be a neoliberal agenda. Only those things that would involve money 
and economic growth are the priority of LGUs as manifested in their correspondence involved in the study. Ultimately, there are politicians that go beyond the call of duty and look for rooms to be improved on. The technocratic and the non-traditional approach of these politicians has helped the efforts of conservation groups to fight for intangible food heritage and heritage conservation in general. Proactivity is indeed the key for these policymakers to counter the adverse implications of globalization.

\section{Knowledge and Awareness}

As mentioned in the preceding discussion, knowledge and sense of awareness are crucial in policymaker's decision making. Their background and approach to governance influences the policy-making process and the stance of the overall administration whether local or national. The politicians' level of perception ultimately steers their LGUs approach based on their a-priori or aposteriori plans or policies. Most of the local executives in Luzon have no prior background on conservation and heritage management. Qualifications for the tourism officer's position mostly depend on trust, confidence, and nepotism. Hence, defeating the purpose of bureaucracy. Most of the LGUs have no tourism offices and normally placed under the Planning and Development Office. This kind of administrative structure is not an ideal model for serious heritage conservation advocacies since decisions basically come from people not capable nor qualified for heritage management let alone tourism product development. Generally, this has been one of the common issues in Philippine Local Government Administration since it is explicitly stated in the 1987 Constitution that anyone can run for public office as long as they can read and write. What lacks in the law of the land is the emphasis on qualification especially for important positions. Although almost the entire key informant pool had college degrees and graduate schooling qualifications, most of the researchers' inquiry resulted to lack of proper knowledge and awareness on heritage conservation. Thus, supporting the result of the mapping method completed by the researchers. 


\section{Readiness and Openness}

Proactivity rather than reactivity is ideally the best approach that a certain LGU must practice on its jurisdiction. However, this has also been a major issue on the part of majority of local chief executives. Rooting from the previous discussion, awareness plays an important role in leadership along with the readiness and openness by practicing anticipatory approaches. Being proactive is foreseeing what is likely to happen in the future and as a leader, this must be a practice in heritage conservation. However, majority of the LGUs have been practicing the traditional politics and governance which lack the anticipatory measures on key aspects of public administration specifically on addressing heritage issues and concerns. Readiness and openness as practiced by several LGUs in the study have paved the way for exemplifying good practice of governance or as the Department of Interior and Local Government puts it, worthy of receiving Seal of Good Housekeeping. This program is a good way of encouraging more LGUs to perform better and achieve more positive outcomes especially on heritage conservation and other sustainable development practices in their jurisdiction's cultural properties. The LGU of Cabagan in Isabela is a good example of this good practice. As mentioned in the table, the LGU created and implemented an ordinance that protects their very own Pancit Cabagan and declared the dish as one of the Intangible Cultural Heritage and symbol of the town that facilitated better tourism growth.

\section{Sustainability}

Sustainable practices within LGUs have become a trend in Philippine public administration. Policymakers began to adopt the principle and immersed themselves into this academic theory turning into real life practice. Heritage conservation is one of the aspects that respects sustainable approaches for future generations. Hence, LGUs must live up to the challenge and push further to achieve its objectives. Knowledge and awareness are keys to this for the implementation of policies of LGUs. Policymakers must have the readiness and openness to adapt to change and 
new trends in the world of governance especially in facing challenges in their jurisdictions. However, heritage conservation especially on intangible cultural heritage has always been neglected by policymakers because of the lack of the basic things that they must profess, political will through knowledge, awareness, readiness, and openness as previously discussed. Majority of the LGUs are struggling with the negative effects of local politics and other priorities not aligned with the principles of sustainability from the system and political climate to prioritization of plans. In line with this, it is difficult for conservation groups to penetrate the political spectrum without support from the LGU. LGUs have often neglect the importance of having long-term plans for their jurisdiction because of the system. Nevertheless, hope is still present if plans made up by the outgoing administration shall be sustained and continued. This will bring us back to the questions of prioritization and political will, level of knowledge and awareness, degree of openness and readiness, and lastly the willingness of the LGU to engage and participate as the primary mover.

\section{Engagement and Participation}

The willingness of all stakeholders, especially the LGUs is crucial for their engagement and participation which will be the turning point and important foundation of heritage conservation. As discussed at the start of the paper, in the field of cultural heritage conservation and conservation science, policymakers are perceived to have a significant role when it comes to decision-making, as these individuals are critical stakeholders who constitutionally and personally benefit through historical past and its preservation which will eventually reflect their value for the identity and cultural properties of the jurisdiction. It is rare to see politicians who value the importance of the latter. The town of Cabagan in the province of Isabela; the entire province of Bataan; the towns of Bocaue and Marilao in Bulacan province; San Jose City in Nueva Ecija province; Lipa City in Batangas province; San Pablo City in Laguna province; the town of Lucban in Quezon province; Puerto Princesa City in Palawan; and the town of Daraga in Albay province are worthy of mentioning for their great works on recognizing their respective Pancit dishes by means of 
recognition for the local cooks and restaurant owners and establishments. There are even efforts of creating ordinances and local policies just to protect their cultural properties. Thus, it is commendable what these LGUs have done to propagate and promote the value and significance of their heritage which the future generation will benefit and learn from. These LGUs and their local population have chosen to engage. The degree of participatory engagement of both the LGUs and the people is worthy of praise and admiration. By engaging and participating on conservation efforts as stated by the informants during interviews, they have secured their future and their identity as manifested by their culture and heritage.

\section{Looked into the role of a selected Higher Educational Institution as a contributor to LGUs on the preservation of food heritage}

\section{Advocacy: The Need and Commitment}

Higher Educational Institutions (HEI) play a remarkable role on heritage protection and conservation. HEls primarily act as the think-tank and arms of government agencies and LGUs through partnerships and collaborations. Thus, creating a harmonized function from both sectors to reach a common goal. Examples of which are many LGUs in the Philippines tap local universities to do research and eventually transform the evidence from the research to policies. This creates a good and ideal practice on promoting evidence-based policy making. The University of Santo Tomas Graduate School - Center for Conservation of Cultural Property and Environment in the Tropics (USTGS-CCCPET), headed by Dr. Eric B. Zerrudo, continues to be a partner of LGUs around the country to conduct studies and trainings on cultural and heritage conservation from all ends of the movement. A research-based project of the center was completed by Mr. Jame Monren T. Mercado as the lead researcher influenced the Lipa City LGU to make Lomi as one of the official identities of Lipa City, Batangas. The center also provided outstanding works all throughout the archipelago to promote evidence and knowledge-based 
policy making vis-à-vis cultural property and environment with an emphasis on historic, aesthetic, social and scientific significance.

Holy Angel University Center for Kapampangan Studies is undoubtedly one of the HEls which actively promotes and conserves the rich culture and heritage of the province of Pampanga by infusing and institutionalizing the Kapampangan (people from Pampanga) Studies into their curriculum relative to their course offerings. An example is the HAU's School of Hospitality and Tourism Management which offers a subject concentrated on Kapampangan Cuisine for the students. The rich traditions of Kapampangans are undeniably rooted on the heritage and identity of the whole country. This move to further promote the intangible cultural heritage through institutionalization has created a positive impact on the awareness of the youth on their identity and history.

Felice Prudente Sta. Maria, a well-known advocate and professor of culture and heritage conservation from the University of the Philippines published a study on the subject matter. Her work GAMBILÀ: A Preliminary Framework for the Study of Philippine Culinary History with Multidisciplinary Impact on Contemporary Social Reality, sparked an influence on many culture and heritage researchers and academicians to further explore the niche and help LGUs and other government agencies to establish projects on Philippine culinary culture.

The work highlighted the importance of culinary heritage research, the different efforts to highlight Philippine culinary heritage by means of publications, events and programs, and proposed a research framework for studying culinary heritage of the Philippines (Sta. Maria 2005). There are still countless of HEls contributing to culture and heritage conservation movement and the need for this endeavor continues as the threat on the subject continues. The need to protect the Filipino identity as manifested by its rich culture, heritage, and tradition is primarily the mission and commitment of these HEls through research, innovation, knowledge-sharing, and implementation of plans, projects, and evidence-based policies dedicated to the preservation, 
promotion, and ultimately the awareness on its multi-disciplinal significance of culture and heritage.

\section{Identity: Our Cultural Heritage}

A country with a strong culture is a formidable country. The identity of Filipinos is heavily rooted on their Culture and Heritage. Thus, the role played by HEls in the Philippines goes beyond academics. It is part of the nation-building and preparation for the future generations. It is a daunting task to be advocates of culture and heritage especially on situations that these HEls feel the lack of support from the government. It has really been the challenge for the HEls because the penetration into the community where the cultural resources are located is not possible without the endorsement and support of LGUs which is discussed in the first research question. The outstanding works of HEls in the country of being part of the conservation movements are the very reason why the spirit of culture and heritage still manifest. The advocacy and pressure they create especially on LGUs to act on its duties on conservation efforts are reasons why the interest and awareness on the subject still abounds. The knowledge and expertise they provide to all sectors and levels of the government are primarily the very basis for robust policies on culture and heritage.

\section{Tomorrow: Sustainability and the Future}

The role of both the HEls and policy makers is of great importance in both policy development and implementation, since these individuals are expected to formulate, debate, and enact policies. Thus, sustainability is relative on Policy makers because they represent governmental body, political parties, public or private institutes, interest groups, and people who establish a direction and urgency for an action to benefit a society, a nation, or community (Lee, 2016). Policies act as instrument to protect cultural and heritage manifestations therefore placing an evidence-based policy through the help of HEls can pave the way to a more robust and sound 
policies anchored on the principles of sustainability. The Brundtland Commission states the Sustainable Development is a development that meets that needs of the present generation without compromising the ability of the future generation to meet their own needs (Brundtland Commission, 1987). Emphasizing the principles of sustainability on local policies has not just becoming a trend but a necessary measure to counter the adverse effects of globalization specifically cultural degradation. The Civil servants with the help of the HEls are frequently engaged directly to the heritage sector and later become witnesses to the actual difficulties and challenges faced by the subject matter. They have become witness to the issues and concerns faced by the conservationist because of the opposing views on the subject matter. An example of this would be the tangible cultural heritage of most towns in the Philippines. No matter how strong the historical significance, like the ancestral house of the mother of the Philippine national hero Dr. Jose Rizal, threats on demolishing the house for one reason to another still lingers around the corner. With this, as mentioned in the preceding discussions, awareness, prioritization, and political will are needed to curb the challenge with the help of the academe to further infuse the soul of these cultural and heritage treasures through the retrospection of the past, enriching the present and securing the future generation of their identity as Filipinos.

\section{Created recommended plan of action to support food heritage policy development}

The Government and the Academe Partnership is a growing trend nowadays in the sphere of public administration and governance. Policies are indeed the vital mechanism in preserving culture and heritage-based resources of a locality. Research on the other hand plays a significant role in policy making by infusing evidence-based decision making and collective participation among stakeholders especially the local communities. The tabular representation below explains the policy making process that aims to guide key-players in their decision-making: 
Table 4. Enhanced and Contextualized Recommended Actions to Support Heritage Policy Development in the Philippines (contextualized from Lee, 2015)

\begin{tabular}{|c|c|c|c|}
\hline & $\begin{array}{c}\text { Planning and } \\
\text { Preparation Stage }\end{array}$ & Drafting Stage & $\begin{array}{c}\text { Implementing and } \\
\text { Directing Stage }\end{array}$ \\
\hline $\begin{array}{l}\text { What to clarify: } \\
\text { Aims, Objectives, } \\
\text { and Targets }\end{array}$ & $\begin{array}{l}\text { What do we want } \\
\text { from policymakers }\end{array}$ & $\begin{array}{c}\text { Method of } \\
\text { decision-making }\end{array}$ & Research priority \\
\hline What to research & $\begin{array}{l}\text { 1. Heritage Mapping } \\
\text { 2. Benefits of heritage } \\
\text { 3. Identification of } \\
\text { contemporary and } \\
\text { issues } \\
\text { problems }\end{array}$ & $\begin{array}{c}\text { Actors in } \\
\text { decision-making }\end{array}$ & $\begin{array}{l}\text { 1. Instruments to } \\
\text { evaluate the } \\
\text { quality of a } \\
\text { policy \& Post- } \\
\text { 2. Pre \& Pre } \\
\text { Evaluation }\end{array}$ \\
\hline What to research & $\begin{array}{l}\text { Strategic \& other } \\
\text { relevant } \\
\text { documents } \\
\text { Benefit of nature } \\
\text { of heritage and } \\
\text { heritage } \\
\text { conservation }\end{array}$ & $\begin{array}{l}\text { List of priorities } \\
\text { (action plan) } \\
\text { With statistical or } \\
\text { scientific data } \\
\text { evidence }\end{array}$ & $\begin{array}{lr}\text { Relevant } & \\
\text { information } & \text { by } \\
\text { topic } & \text { for } \\
\text { implementing } & \text { a } \\
\text { policy } & \end{array}$ \\
\hline $\begin{array}{l}\text { Guiding and } \\
\text { Theoretical } \\
\text { Principles }\end{array}$ & $\begin{array}{l}\text { Must be easy to } \\
\text { understand } \\
\text { contextualized in } \\
\text { the locality }\end{array}$ & $\begin{array}{l}\text { Political Science } \\
+\quad \text { Public } \\
\text { Administration + } \\
\text { Heritage and } \\
\text { Conservation } \\
\text { Research }\end{array}$ & $\begin{array}{l}\text { Evidence-driven } \\
\text { implementation }\end{array}$ \\
\hline $\begin{array}{l}\text { For whom: The } \\
\text { Stakeholders }\end{array}$ & $\begin{array}{l}\text { Policy-maker } \\
\text { (LGUS), HEls and } \\
\text { the Public }\end{array}$ & $\begin{array}{l}\text { Policy-maker } \\
\text { (LGUs) and HEIs }\end{array}$ & $\begin{array}{l}\checkmark \text { Policy-maker } \\
\text { (LGUs) } \\
\checkmark \text { HEIs through } \\
\text { Research and } \\
\text { Service- } \\
\text { Learning } \\
\text { Programs } \\
\sqrt{\text { (PRAXIS) }} \\
\sqrt{\text { Contractors }} \\
\text { Heritage } \\
\text { experts }\end{array}$ \\
\hline
\end{tabular}

The tabular representation considers the three different stages of policymaking and gives a list of aspects for each stage to be clarified, studied, analyzed, and prepared by LGUs, conservation scientists, academicians and other heritage professionals involved in policymaking. This aims to guide the stakeholders to have a holistic basis of their management from the planning, implementation, to assessment stages. The mapping approach of significant cultural assets of a locality has always been the task of the national and partner HEls which is true for the 
USTGS-CCCPET. HEIs, as mentioned in the early discussions act as the think-tank of the whole process with the LGUs as the implementers and funds a project. The theoretical background of this projects is heavily dependent on the knowledge and capability of the HEls. Ultimately, partnership and collaboration play a significant role in knowledge sharing and holistic public policy development.

\section{DISCUSSION}

Noodle is perhaps one of the most popular staples around the world. From east to west, there are myriad of delicacies and dishes native from different regions. Asia, with its range of rich cultural diversity, is remarkably the epicenter where one can find the best variety of noodle dishes that astounded the culinary world by storm and since then propagated to different annals of gastronomic mainstays, from posh European restaurants to small and humble eateries on Asian alleys. Pancit is a Filipino noodle dish flavored with seafood and/or meat and/or vegetables (Fernandez, 2000). Classic memories from family gatherings to typical school-day recess would be accompanied by snack with the most common Filipino carbohydrate source next to rice, pancit. It can be eaten and enjoyed on its own, or as bizarre as it sounds, even consumed with rice or as a sandwich filling. Pancit is an acquired taste but with the hundreds of years that this comfort food was enjoyed throughout the Philippine islands made a stimulus that produced a Filipino style noodle dish which represent the natural and cultural abundance of the country featured in festivals or local town fiestas and enjoyed in every household that no one would dare to miss. We agree that Pancit truly is a symbol of Filipinos which, like its noodles, absorbs and airs its firm connection to the richness of our faith, culture, and heritage.

As an identity of the people, food in the context of Filipino affinity with Pancit, shows significance that contributes to its uniqueness and difference as remarkably expressed and showcased with its sundry variations. We can affirm that the affinity of Filipinos with pancit is even 
reinvigorated with its significance. This significance, which the researchers would attest and proven is based on historical, aesthetic, social, and symbolical aspects. It is important to analyze these details as they contribute to the story and importance of the community and how food evolves and develops as part of the heritage of the people (Mercado \& Andalecio, 2020). The researcher believes that more than having the privilege to complete the project, the life changing experience acquired through in-depth interregional hopping and going deep to community's shared traditions on the most revered noodle dish in the Philippines for centuries is a fantasy fulfilled. From the meticulous process of cooking, selling, and consumption, the researcher was amazed and at the same time concerned by the results of year-long digging-deep into the sustainability of communal shared traditions of pancit making as an industry, to the complexity of the statutory milieu of national and local governance.

Pawson (2002) stated that research should attempt to pass on collective wisdom about the successes and failure of previous initiatives in particular policy domains. This is ultimately the role of both the governments and the academe as the primary stakeholders of development. According to him the prize is also a big one that such an endeavor could provide the antidote to policy making's frequent lapses into crowd pleasing, political pandering, window dressing and god-acting. Hence, research-based policy making is necessary for culture and heritage conservation goals. Mulgan (2003) further explains evidence-based policy must be systematic and scientific and not the traditional schemes of policy making. Understanding of evidence-based policy tend to differ, however in the study conducted by Reid (2003) as cited in O'Dwyer (2004), a great number of policy makers used the term to suggest that policy was substantially informed by data and proof.

\section{CONCLUSION}

In the field of cultural heritage conservation, the researcher witnessed that policymakers and the academe have significant roles when it comes to decision-making and knowledge 
sharing, as these individuals are critical stakeholders who constitutionally and personally benefit through historical past and its preservation. Travelling the terrain and crossing the seas of Luzon, the biggest island group in the country, the researcher witnessed first-hand the situation and reality of both communities and the state of governance vis-à-vis heritage conservation. The researcher can confirm that Local Governments and the Academe are the main driving force that can steer this advocacy. However, in the part of LGUs, sheer political will, knowledge, and awareness on pressing issues on heritage conservation, openness, sustainable practices, and multi-stakeholder participation are essential if we want to see a robust protection vis-à-vis culture and heritage conservation in general. This comes with the active participation of other stakeholders especially the academic institutions which provide expertise and extra leg work on research backed by their advocacy rooted on Filipino identity and sustainability to back policies of the government. Ultimately, research-based policy making is key to open the vast opportunities not just on intangible cultural heritage but on culture and heritage conservation in the general.

The research project focused on the essential stakeholders in the context of food heritage research and public policy in the island of Luzon, the Philippines. Twenty (20) provinces, twentyseven (27) cities and twenty-six (26) municipalities, an impressive total of one hundred and one (101) pancit dishes were mapped, further explored in the study, and presented as the highlight of the investigation. For future researchers, a quantitative approach can further boost its conclusiveness for positivist researchers. The research project is just on its preliminary stage and will further explore the remaining island groups of Visayas and Mindanao.

\section{REFERENCES}

Australia ICOMOS. The Burra Charter: The Australia ICOMOS Charter for Places of Cultural Significance. Australia ICOMOS. 2013. https://australia.icomos.org/wp-content/uploads/TheBurra-Charter-2013-Adopted-31.10.2013.pdf. Accessed 20 Nov 2019.

Boyce C, Neale P. (2006). Conducting in-depth interviews: a guide for designing and conducting in-depth interviews for evaluation input. Pathfinder International: Massachusetts.

Commission on Higher Education (2011). Advancing a Locally Responsive and Globally 
Competitive Philippine Higher Education System. Higher Education Accomplishments, 20102016. https://ched.gov.ph/wp-content/uploads/2017/09/Higher-Education-Accomplishments2010-2016.pdf

Fernandez D. (2000). Palayok: Philippine food through time, On Site, In the Pot. Makati City: Bookmark.

Lee, S. (2015). Working with policy-makers for integrating heritage science research into political priorities, Studies in Conservation, 60:sup2, 48-56. doi: 10.1080/00393630.2015.1117865

Mercado, J.M.T. \& Andalecio, A.B.P. (2020). Ysla de Panciteria: a preliminary study on the culinary heritage significance of pancit using the heritage documentation approachthe case of Luzon Island, Philippines. J. Ethn. Food 7, 19. doi: 10.1186/s42779-02000057-1

Md Ramli, A., Mohd Zahari, M. S., Suhaimi, M. Z., \& Abdul Talib, S. (2016). Determinants of Food Heritage towards Food Identity. Environment-Behaviour Proceedings Journal, 1(1), 207216. https://doi.org/10.21834/e-bpj.v1i1.217

Mulgan, G. (2003). Government, knowledge and the business of policy making, Canberra Bulletin of Public Administration, vol. 108, pp. 1-5.

O'Dwyer, L. (2004). A critical review of evidence-based policy making. AHURI Final Report

No. 58. Australian Housing and Urban Research Institute - Southern Research Centre. https://www.ahuri.edu.au/_data/assets/pdf_file/0016/2248/AHURI_Final_Report_No58_A_ critical_review_of_evidence_based_policy_making.pdf

Pawson, R. (2002). 'Evidence-based policy: In search of a method', Evaluation, April 8(2), pp. 157-181.

Shariff, N. M., Mokhtar, K., \& Zakaria, Z. (2008). Issues in the Preservation of Traditional Cuisines: A Case Study in Northern Malaysia. International Journal of the Humanities, 6(6), 101-106 Sta. Maria F. (2016). What Kids Should Know About Filipino Food. Quezon City: Adarna House UNESCO. (1972). The Convention for the Protection of the World Cultural and Natural Heritage. United Nations Educational, Scientific and Cultural Organization.

1972. http://whc.unesco.org/en/conventiontext/. Accessed 23 Nov 2019.

UNESCO. (2003). The convention for the safeguarding of the intangible cultural heritage.

United Nations Educational, Scientific and Cultural Organization. 2003. https://ich.unesco.org/doc/src/15164-EN.pdf. Accessed 23 Nov 2019.

UNESCO. (2008). World Heritage Information Kit. France: UNESCO World Heritage Center Retrieved from http://whc.unesco.org.

Wahid, N. A., Mohamed, B., \& Sirat, M. (2009). Heritage food tourism: bahulu attracts? Paper presented at the Proceedings of 2nd National Symposium on Tourism Research, Universiti Sains Malaysia, Penang, Malaysia 18 July 2009. Theories and Applications.

Zerrudo E. (2008). Pamanaraan: Writings on Philippine Cultural Heritage Management. Manila: UST Publishing House; 2008. 


\section{APPENDIX}

\begin{tabular}{|c|c|c|c|c|c|}
\hline $\begin{array}{c}\text { Regional } \\
\text { Code }\end{array}$ & $\begin{array}{c}\text { Name of the } \\
\text { Region }\end{array}$ & Province & $\begin{array}{c}\text { City or } \\
\text { Municipality }\end{array}$ & $\begin{array}{c}\text { Name of the } \\
\text { Pancit }\end{array}$ & Policies \\
\hline \multirow[t]{4}{*}{ Region I } & $\begin{array}{l}\text { Ilocos Region/ } \\
\text { Ilocandia }\end{array}$ & Ilocos Norte & Batac City & Miki & $\begin{array}{l}\text { Incentives for tax and business permit } \\
\text { requirements. The introduction of the } \\
\text { Empanada Festival also highlights Batac Miki } \\
\text { Noodles. }\end{array}$ \\
\hline & & & Laoag City & Hibol & None \\
\hline & & & & Pancit Lusay & None \\
\hline & & Ilocos Sur & Vigan City & Pancit Musiko & None \\
\hline \multirow[t]{5}{*}{ Region II } & $\begin{array}{l}\text { Cagayan Valley } \\
\text { PNorthern } \\
\text { Philippines }\end{array}$ & Cagayan & Aparri & Miki Nilad-dit & $\begin{array}{l}\text { Recognized by the Barangay Makanaye } \\
\text { through the implementation of Miki Nilad-dit } \\
\text { Cooking Contest. This is a community effort } \\
\text { to continuously practice the tradition and } \\
\text { promotion to the future generation. }\end{array}$ \\
\hline & & & $\begin{array}{c}\text { Tuguegarao } \\
\text { City }\end{array}$ & $\begin{array}{l}\text { Pancit Batil } \\
\text { Patong }\end{array}$ & $\begin{array}{l}\text { DOT and the LGU is in full support in terms } \\
\text { of marketing and promotions program by } \\
\text { featuring the dishes at food fairs, festivals. } \\
\text { and travel shows. }\end{array}$ \\
\hline & & & & Sinanta & $\begin{array}{l}\text { DOT and the LGU is in full support in terms } \\
\text { of marketing and promotions program by } \\
\text { featuring the dishes at food fairs, festivals, } \\
\text { and travel shows. }\end{array}$ \\
\hline & & & & & $\begin{array}{l}\text { Municipal Ordinance No. } 35, \text { s. } 2011 \\
\text { recognizing Pancit Cabagan as one of the } \\
\text { intangible cultural heritages of the town. }\end{array}$ \\
\hline & & Isabela & Cabagan & Pancit Cabagan & $\begin{array}{l}\text { Pancit Festival is also held annually. The } \\
\text { LGU also documented the tradition by by } \\
\text { means of cultural heritage mapping and } \\
\text { submitted it to the National Commission for } \\
\text { Culture and the Arts (NCCA) for PRECUP. } \\
\text { Most of the restaurants are already } \\
\text { accredited and awarded by the Department } \\
\text { of Trade and Industry (DTI) and the } \\
\text { Department of Health (DOH). }\end{array}$ \\
\hline CAR & $\begin{array}{l}\text { Cordillera } \\
\text { Administrative } \\
\text { Region }\end{array}$ & Abra & Bangued & Abra Miki & $x^{-1}$ \\
\hline \multirow[t]{7}{*}{ Region III } & Central Luzon & Bataan & Balanga City & Pancit Kupang & $\begin{array}{l}\text { The LGU of Balanga City awarded Ms. } \\
\text { Estrella de Mesa and her business with } \\
\text { Dangal Balangueno. } \\
\text { The provincial and the city government is } \\
\text { continuously helping Mrs. De Mesa in terms } \\
\text { of promotions and marketing. }\end{array}$ \\
\hline & & & Morong & Hu Tieu & $\begin{array}{l}\text { The LGU and the provincial government are } \\
\text { working hand-in-hand with the business } \\
\text { establishments in the promotion of the } \\
\text { culinary dish especially on media coverages } \\
\text { and research opportunities. }\end{array}$ \\
\hline & & & Orani & Pancit Palabok & $\begin{array}{l}\text { The LGU and the provincial government } \\
\text { recognize Chedeng's Pancitan as one of the } \\
\text { tourist attractions of the province of Bataan } \\
\text { specifically in the municipality of Orani. }\end{array}$ \\
\hline & & & & & $\begin{array}{l}\text { The establishment is also recognized by the } \\
\text { LGU as one of the intangible cultural } \\
\text { heritages of the town especially on its } \\
\text { culinary significance. }\end{array}$ \\
\hline & & & & Spabok & $\begin{array}{l}\text { The provincial and city government are } \\
\text { helping the establishment in terms of } \\
\text { marketing and promotions aspect as one } \\
\text { way of recognizing the dishes. }\end{array}$ \\
\hline & & Bulacan & Bocaue & $\begin{array}{l}\text { Batchoy } \\
\text { Tagalog }\end{array}$ & None \\
\hline & & & & $\begin{array}{l}\text { Pancit } \\
\text { Alanganin }\end{array}$ & $\begin{array}{l}\text { The provincial govemment of Bulacan recognizes the } \\
\text { family for promoting the province's a innary identity by } \\
\text { giving the Culinary Hertage Award. The LGU is also } \\
\text { promotes the restaurant and the culnary dish to various } \\
\text { media and other platforms (i.e. academic researches). }\end{array}$ \\
\hline
\end{tabular}




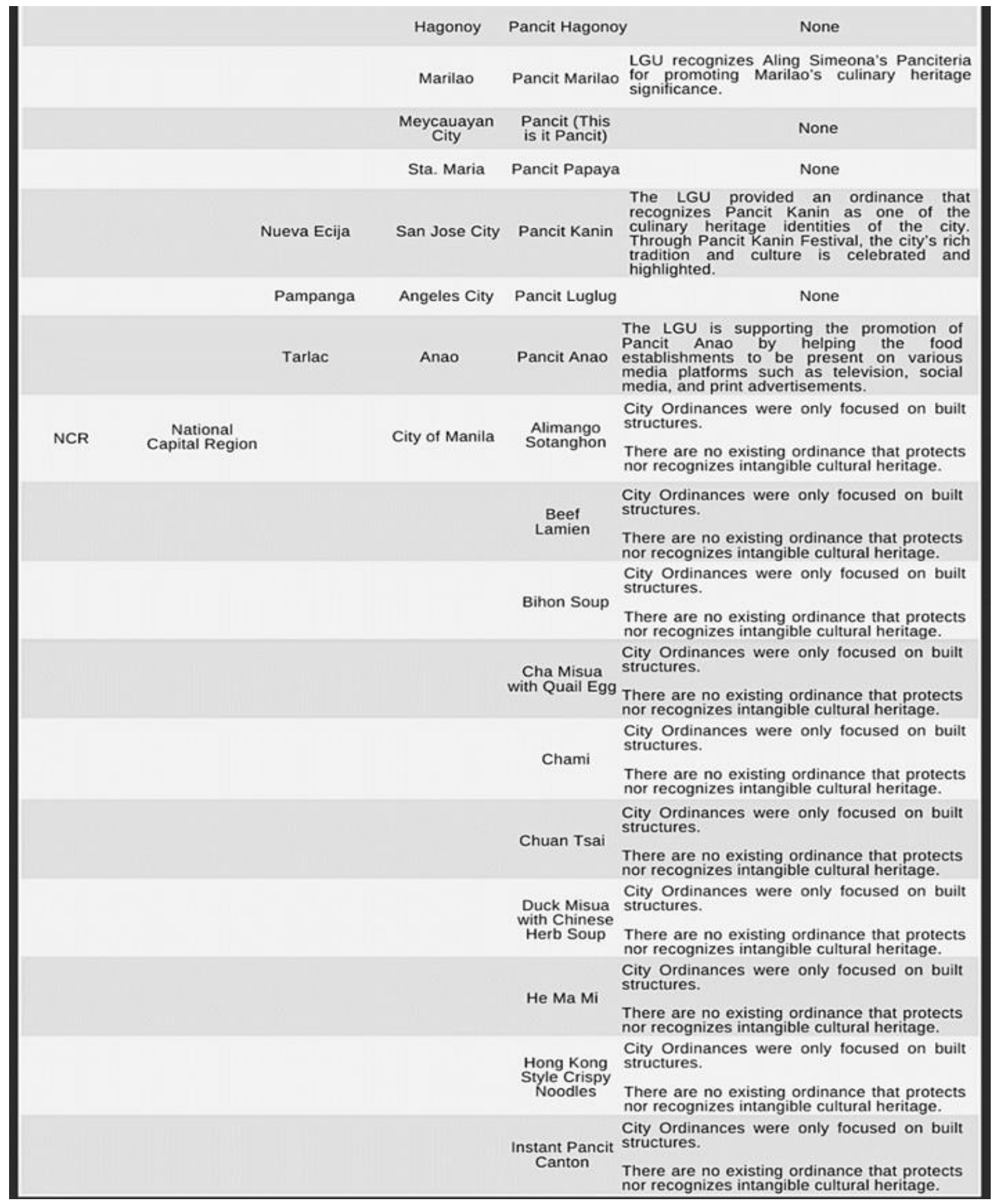


Kiam Tsai

City Ordinances were only focused on built structures.

There are no existing ordinance that protects nor recognizes intangible cultural heritage.

City Ordinances were only focused on built

Lobihon structures.

There are no existing ordinance that protects nor recognizes intangible cultural heritage.

City Ordinances were only focused on built

Lomisua

There are no existing ordinance that protects nor recognizes intangible cultural heritage. City Ordinances were only focused on built

Ma Chi On structures.

There are no existing ordinance that protects nor recognizes intangible cultural heritage.

City Ordinances were only focused on built

Maki Mi structures.

There are no existing ordinance that protects nor recognizes intangible cultural heritage.

City Ordinances were only focused on built structures.

Miki Bihon

Soup

There are no existing ordinance that protects nor recognizes intangible cultural heritage.

City Ordinances were only focused on built

Misuaco

There are no existing ordinance that protects nor recognizes intangible cultural heritage.

City Ordinances were only focused on built

Owwa Miswa structures.

There are no existing ordinance that protects nor recognizes intangible cultural heritage.

City Ordinances were only focused on built

Pancit Canton structures.

Lo Han Chay

There are no existing ordinance that protect nor recognizes intangible cultural heritage.

City Ordinances were only focused on built

Pancit Canton structures.

There are no existing ordinance that protects nor recognizes intangible cultural heritage.

City Ordinances were only focused on built

Pancit Satae structures.

Mi Guisado

There are no existing ordinance that protects nor recognizes intangible cultural heritage. City Ordinances were only focused on built

Pata Bihon structures.

There are no existing ordinance that protects nor recognizes intangible cultural heritage.

City Ordinances were only focused on built

Shui Jiao structures.

Mian

existing ordinance that protects nor recognizes intangible cultural heritage.

City Ordinances were only focused on built structures.

Sizzling

There are no existing ordinance that protects nor recognizes intangible cultural heritage.

City Ordinances were only focused on built

Tomato Bihon structures.

There are no existing ordinance that protects nor recognizes intangible cultural heritage. 


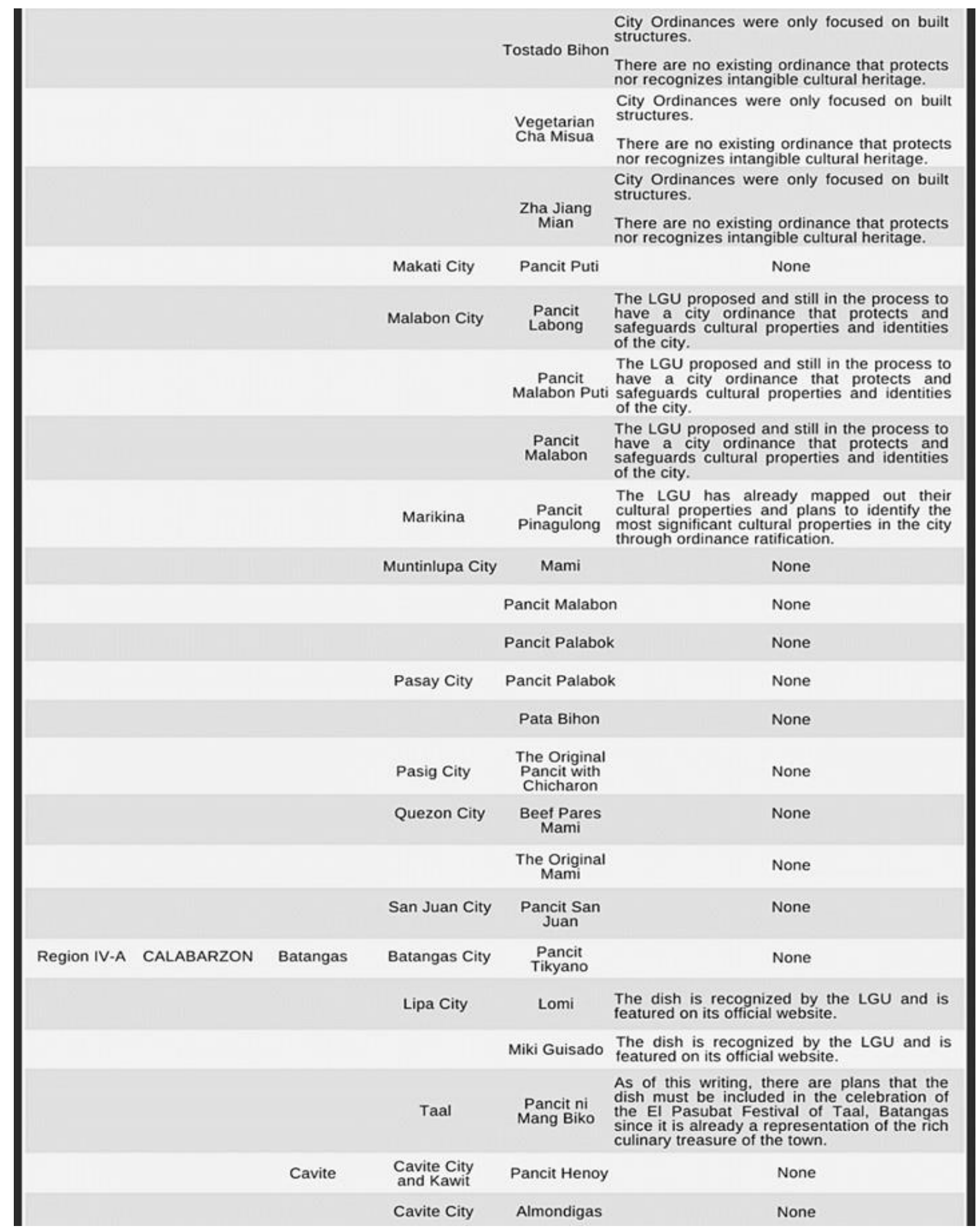




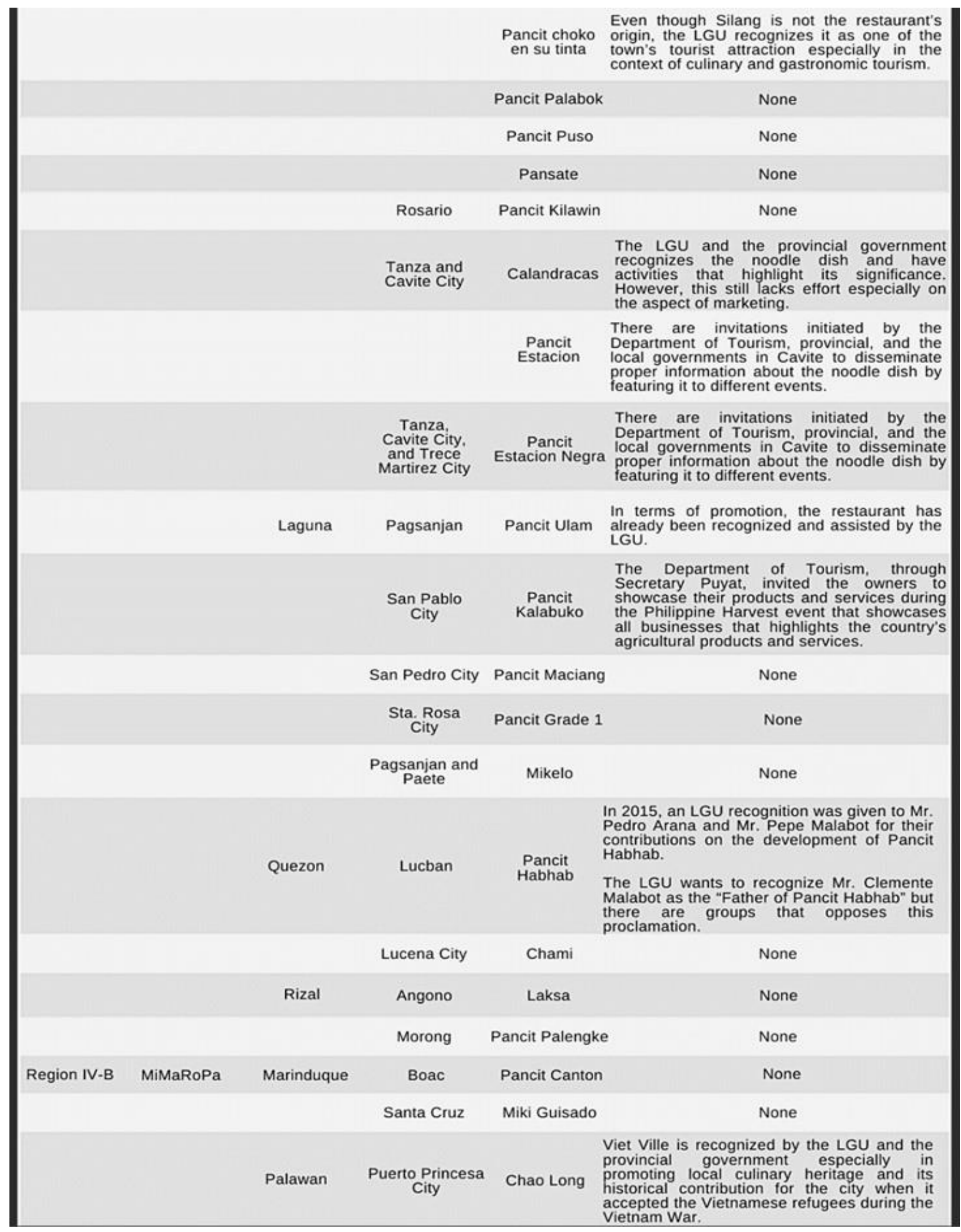




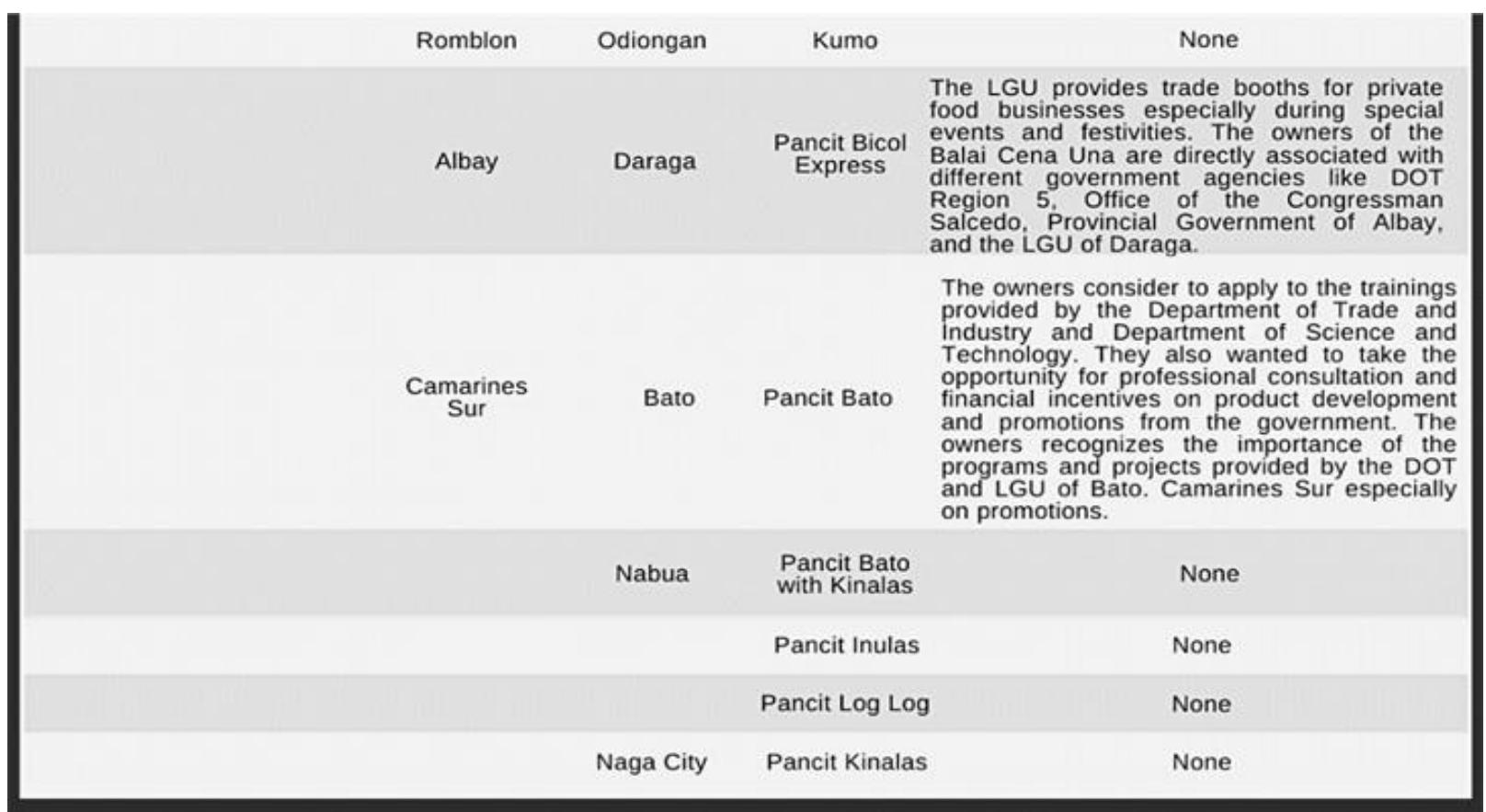

